\title{
Oxygen Consumption Rate of Polychaeta Nereis sp. Different Sizes and Type of Feed
}

\author{
Eko Setio Wibowo*, Endah Sri Palupi, I G A Ayu Ratna Puspitasari and Atang \\ Faculty of Biology, Jenderal Soedirman University \\ Jl. dr. Soeparno No.63 Purwokerto 53122, Indonesia \\ Email: tio_eko@yahoo.co.id
}

\begin{abstract}
Nereis sp. contains amino acids and unsaturated fatty acids that can improve the quality of gamete stem cells and the quality of the resulting larvae. Nereis sp. can increase gamete cell maturation in the parent shrimp up to $70 \%$. This triggers the exploitation these worms excessively in nature since there are no cultivation efforts to meet their needs. This condition encourages research on the biological aspects of Nereis sp. to complement the information that can support the cultivation of the worms. This research was conducted on Nereis $s p$. from the Jeruklegi Cilacap area with different types of feed. This study aims to determine the metabolic rate of the worms Nereis sp. at different sizes by giving different types of feed. This research use immature Nereis $s p$. which was maintained at 15 ppt salinity with three different body weight (0.3-0.6 g; 1.1-1.3 g and 1.8-2.04 g) with three different types of feed (DO feed, feed flour of Spirulina sp. and ornamental fish feed tetra blitsz). The study was conducted experimentally with a randomized block design (RBD) method with six replications. The results showed the rate of oxygen consumption of Nereis $s p$. influenced by the size and type of feed given $(P<0.05)$. Nereis $s p$. with size of 0.3-0.6 gr indicates the highest metabolic rate. Nereis $s p$. fed with flour of Spirulina sp. shows the highest metabolic rate. Appropriate feed to support the growth of Nereis sp. is DO and tetra blits (low fiber feed).
\end{abstract}

Keywords: worms, feed, oxygen consumption, weight, Nereis sp.

\section{Introduction}

Nereis sp. is a member of Polychaeta, Nereidae, which live in the estuarine ecosystem as benthic but also actively swim in the waters when reproducing (Wallace et al., 1991). Wibowo et al. (2018) found the worms, Nereis sp., in Jeruklegi pond area of Cilacap in the water with salinity of 930 ppt, but live optimally at 5-15 ppt (Wibowo et al., 2019). In regard to food, these worms can digest the remains of plants and animals by swallowing the surface of sediments in the form of organic matter resulting from degradation from aerobic microbial and anaerobic processes in the form of proteins, cellulose, and lignin (Kristensen, 2000).

Worms Nereis sp. which is maintained at 15 ppt salinity, fed with the main content of animal protein and the main content of vegetable protein shows that the survival is not different with survival rate ranging from 60-70\% (Wibowo et al., 2019). Nereis worms with zooplankton feed show faster growth compared with phytoplankton feed. These are thought to be due to better nutritional value of zooplankton. Zooplankton contains animal protein that is more easily ingest thus, not much energy is needed for digestion and metabolism (Yuwono, 2003).

A feed is a factor that greatly influences the life and growth of Nereis sp. The growth of sea worms is closely related to the availability of protein in the feed because protein is a source of energy for sea worms (Mustofa, 2012). Nereis sp. with animal protein feed experienced higher body weight growth compared to plant protein feed (Wibowo et al., 2019). This condition is also possible because of Nereis sp. tends to be carnivores, so it is more suitable if fed with animal protein content. Appropriate food will be more easily metabolized, thus affecting the energy which will be issued.

Body size factors also affect the amount of energy needed to metabolize so that the rate of oxygen consumption will also be different. The rate of oxygen consumption depends on body size, digestive ability, and ambient temperature Cook et al., 2000). Schmidt-Nielsen (1990) states that measuring oxygen consumption is an easy and practical way to do it and is commonly used to measure metabolic rate. This is because the amount of heat produced per liter of oxygen consumption for metabolism is relatively constant 
both for protein oxidation (4.5 $\left.\mathrm{kcal} / \mathrm{I} \quad \mathrm{O}_{2}\right)$, carbohydrates $(5.0 \mathrm{kcal} / \mathrm{I} \mathrm{O})$, or fat $\left(4.7 \mathrm{kcal} / / \mathrm{O}_{2}\right)$. The result is an average value of $4.8 \mathrm{kcal} / \mathrm{I} \mathrm{O}_{2}$, which can be used as a measure of metabolic rate.

This study aims to determine the rate of oxygen consumption of Nereis $\mathrm{sp}$. At various sizes with different types of feed, so that it will provide information about the appropriate feed to support the life of polychaeta Nereis sp. on various sizes. The results of this study are expected to provide basic information regarding oxygen consumption for the culture of Nereis sp. as an effort to meet the needs of shrimp feed, so it does not rely on exploitation from nature.

\section{Materials and Methods}

Ingredients used worms Nereis sp. immature obtained from the Jeruklegi Cilacap pond area with a bodyweight of 0.3-0.6 g; 1.1-1.3 g and 1.8-2.04 g Jeruklegi Cilacap pond substrate, seawater, freshwater, DO feed, flour of Spirulina sp. and tetra blits (ornamental fish feed), $\mathrm{MnSO}_{4}$ solution, $\mathrm{KOHKI}$ solution, concentrated $\mathrm{H}_{2} \mathrm{SO}_{4}$ solution, $0.025 \mathrm{~N}$ $\mathrm{Na}_{2} \mathrm{~S}_{2} \mathrm{O}_{3}$ solution, starch indicator, and distilled water.

\section{Experimental design}

The study was conducted experimentally with a randomized block design method (RBD) with the following treatments: PDOB1= Maintenance of worms Nereis sp. with a bodyweight of 0.3-0.6 gr and feed with D0. PDOB2=Maintenance of worms Nereis sp. with a bodyweight of 1.1-1.3 g and feed with D0. PDOB3=Maintenance of worms Nereis $\mathrm{sp}$. with a bodyweight of 1.8-2.04 g and feed with D0. PSPB1 = Maintenance of worms Nereis sp. with a bodyweight of 0.3-0.6 $\mathrm{gr}$ and feed with flour of Spirulina sp. PSPB2=Maintenance of worms Nereis sp. with a bodyweight of 1.1-1.3 $\mathrm{g}$ and feed with flour of Spirulina sp. PSPB3=Maintenance of worms Nereis sp. with a bodyweight of 1.8-2.04 g and feed with flour of Spirulina sp. PTBB1=Mainte-nance of worms Nereis sp. with a bodyweight of 0.3-0.6 gr and feed with tetra blits (ornamental fish feed). PTBB2 = Maintenance of worms Nereis sp. with a bodyweight of 1.1-1.3 $\mathrm{gr}$ and feed with tetra blits (ornamental fish feed). PTBB3 = maintenance of worms Nereis sp. with a bodyweight of 1.8-2.04 grams and feed with tetra blits (ornamental fish feed). Each treatment was provided six units as a repetition.

Preparation of culture media, the substrate was taken from the Jeruklegi Cilacap aquaculture area, then dried for $2 \times 24 \mathrm{~h}$. Sludge was put in a test container $(20 \times 30 \mathrm{~cm})$ with a thickness of $5 \mathrm{~cm}$.
Each treatment container was filled with a substrate with 15 ppt water salinity, with a water height of 15 $\mathrm{cm}$, with aeration was then left for 1 (one) week. Nereis sp. were taken from the pond area of Jeruklegi Cilacap, Central Java and immature worms were selected (growth period when the morphology of males and females can not be distinguished, namely brownish red). It is placing test worms, each container filled with 10 worms Nereis sp. that had been acclimating for two weeks. The placement of the test worm is carried out after weighing its initial weight and separated according to its weight range. The study was conducted for two months, and each treatment was fed according to treatment, once a week as much as $2 \%$ of body weight.

\section{Metabolism (oxygen consumption)}

Observation of oxygen consumption parameters was carried out at the end of the study. Oxygen consumption was measured by a respirometer using the Winkler model Fry (1971) method in Brougher et al. (2005). The formula calculates dissolved oxygen according to APHA (2005).

Oxygen consumption (mg.g-1.hour ${ }^{1}$ ) of worm measured using Fidhiany method (1999). Measurement of oxygen consumption is carried out at a water temperature of $25^{\circ} \mathrm{C}$.

$V O_{2}=\left(c O_{2 i}-c O_{2 f}\right) \times V \times H^{-1} \times W^{-1}$

Note : $\mathrm{VO}_{2}=$ Oxygen consumption $\left(\mathrm{mg} \cdot \mathrm{g}^{-1} \cdot \mathrm{h}^{-1}\right) ; \mathrm{cO}_{2 \mathrm{i}}=$ Initial dissolved oxygen (mg. $\left.\mathrm{L}^{-1}\right) ; \quad \mathrm{CO}_{2 \mathrm{f}}=$ Final dissolved oxygen (mg.L-1); $\mathrm{W}=$ Worm Weight (g); $\mathrm{V}=$ The volume of the tube after reducing the volume of worms (I); $\mathrm{H}=$ Time interval for initial and final oxygen measurements (hours).

The data obtained were analyzed statistically using two-way analysis (factorial) followed by Tukey test. The analysis was performed using the MINITAB 16 software program.

\section{Results and Discussion}

The observations showed that the average oxygen consumption rate of Nereis sp. in three different sizes and given three different types of feed ranging from $0.08812-0.56590 \mathrm{mg} \cdot \mathrm{g}^{-1} \cdot \mathrm{h}^{-1}$. The lowest oxygen consumption rate obtained in worms Nereis sp. size 1.8-2.04 g (large size) that is fed Do, and the highest rate of oxygen consumption is highest in worms of size 0.3-0.6 g (small size) with feed flour of Spirulina sp. The rate of oxygen consumption of the worms various body weights maintained with different feed at the end of the experiment (Table 2). 
The results showed that feed and body size/body weight had a significant effect $(P<0.05)$ on the rate of oxygen consumption at the end of the experiment. Table 2 and Figure 1 show that the metabolic rate, in this case, the rate of oxygen consumption of the worms Nereis sp. influenced by the type of feed given. According to Schmidt-Nielsen (1990), oxygen consumption is a picture of direct energy use in metabolic work, including metabolism for the eating and living activities of an organism. These results confirm that the metabolic work of Nereis sp. influenced by the type of feed consumed, which is thought to be related to the composition of the feed and its degradation process.

The results showed that Nereis sp. with fed DO and tetra blits flour, which had a crude fiber content of $6.28 \%$ and $4.31 \%$ had the same oxygen consumption rate $(\mathrm{P}>0.05)$ and significantly different with those fed flour of Spirulina sp. which has a crude fiber content of $14.76 \%$. This result is following Wibowo et al. (2019), who showed Nereis sp., which are maintaineds at salinity of 5, 10 and $15 \mathrm{ppt}$, by being fed with protein animal-based diet have a lower metabolic rate than those fed with plant-based protein. This result is also consistent with the study of Yuwono et al. (2002) in juvenile helminths, which produced higher segment growth with animal protein feed (Brachionus) compared to vegetable protein (Spirullina and Chlorella). This condition occurs because the process of digestion of feed, which contains more fiber, requires energy so that the rate of oxygen consumption becomes greater then growth becomes smaller. According to Ranjhan (1993) in Darmadi et al. (2003), fibrous food will increase the energy needed in the digestive process, so that energy that should be used to increase body tissue is expendeds for the process of digesting fibrous food. According to Cook et al. (2000), Zimmermann and Kunzmann (2001), oxygen consumption will be influenced by changes in the ability of digestibility of feed.

The results also showed the rate of oxygen consumption was influenceds by body weight ( $P$ $<0.05$ ). Oxygen consumption rate of Nereis $\mathrm{sp}$. with a body weight of 0.3-0.6 g and 1.1-1.3 g greater when compared to Nereis $\mathrm{sp}$. with a body weight of 1.8-2.04 g. These results indicate that Nereis sp. smaller ones have a higher metabolic rate or oxygen consumption rate. This phenomenon is following Sherwood et al. (2011), which states that larger animals consume more energy than small animals, but they have a lower metabolic rate than the weight of smaller animals. These results are following Liu et al. (2009), which shows that the rate of oxygen consumption of $N$. japonica worms is inversely proportional to body weight, where the smaller the body weight, the rate of oxygen consumption increases. This result is also in accordance with previous studies which showed the level of oxygen consumption and the rate of excretion of ammonia

Table 1. Proximate composition of feed

\begin{tabular}{cccccccc}
\hline & \% water & \% Dry wight & \multicolumn{5}{c}{$\%$ Crude Fibre (\%) } \\
\cline { 4 - 7 } Feed & & & Protein & Fat & Fiber & Ash & Non-Nitrogen Extract Matter \\
\hline Feed D0 & 7,91 & 92,09 & 31,74 & 9,69 & 6,28 & 7,91 & 44,38 \\
Feed Tetra blits & 7,11 & 92,89 & 39,53 & 7,07 & 4,31 & 7,11 & 41,99 \\
Flour of Spirulina sp, & 8,44 & 3,83 & 59,57 & 0,50 & 14,76 & 8,44 & 16,73 \\
\hline
\end{tabular}

Table 2. Oxygen consumption rate $\left(\mathrm{mg}^{\mathrm{g}} \mathrm{g}^{-1} \cdot \mathrm{h}^{-1}\right)$ of Nereis $\mathrm{sp}$. with various sizes that are maintained with different feeds. Numbers followed by different letters in the same column show significant differences between treatments $(P<0.05)$.

\begin{tabular}{cccl}
\hline No. & Treatment & Range & Average \\
\hline 1 & PDOB1 & $0,23806-0,31508$ & $0,25556 \pm 0,0312^{\mathrm{b}}$ \\
2 & PDOB2 & $0,15139-0,30279$ & $0,22026 \pm 0,0561^{\mathrm{b}}$ \\
3 & PDOB3 & $0,04918-0,12296$ & $0,08812 \pm 0,0251^{\mathrm{c}}$ \\
4 & PSPB1 & $0,30514-0,56590$ & $0,40408 \pm 0,0978^{\mathrm{a}}$ \\
5 & PSPB2 & $0,28851-0,48207$ & $0,36825 \pm 0,0817^{\mathrm{a}}$ \\
6 & PSPB3 & $0,08095-0,25635$ & $0,18664 \pm 0,0529^{\mathrm{d}}$ \\
7 & PTBB1 & $0,23804-0,47159$ & $0,31041 \pm 0,10582^{\mathrm{ab}}$ \\
8 & PTBB2 & $0,15140-0,37849$ & $0,27177 \pm 0,08464^{\mathrm{ab}}$ \\
9 & PTBB3 & $0,04894-0,20800$ & $0,13663 \pm 0,06585^{\mathrm{cd}}$ \\
\hline
\end{tabular}




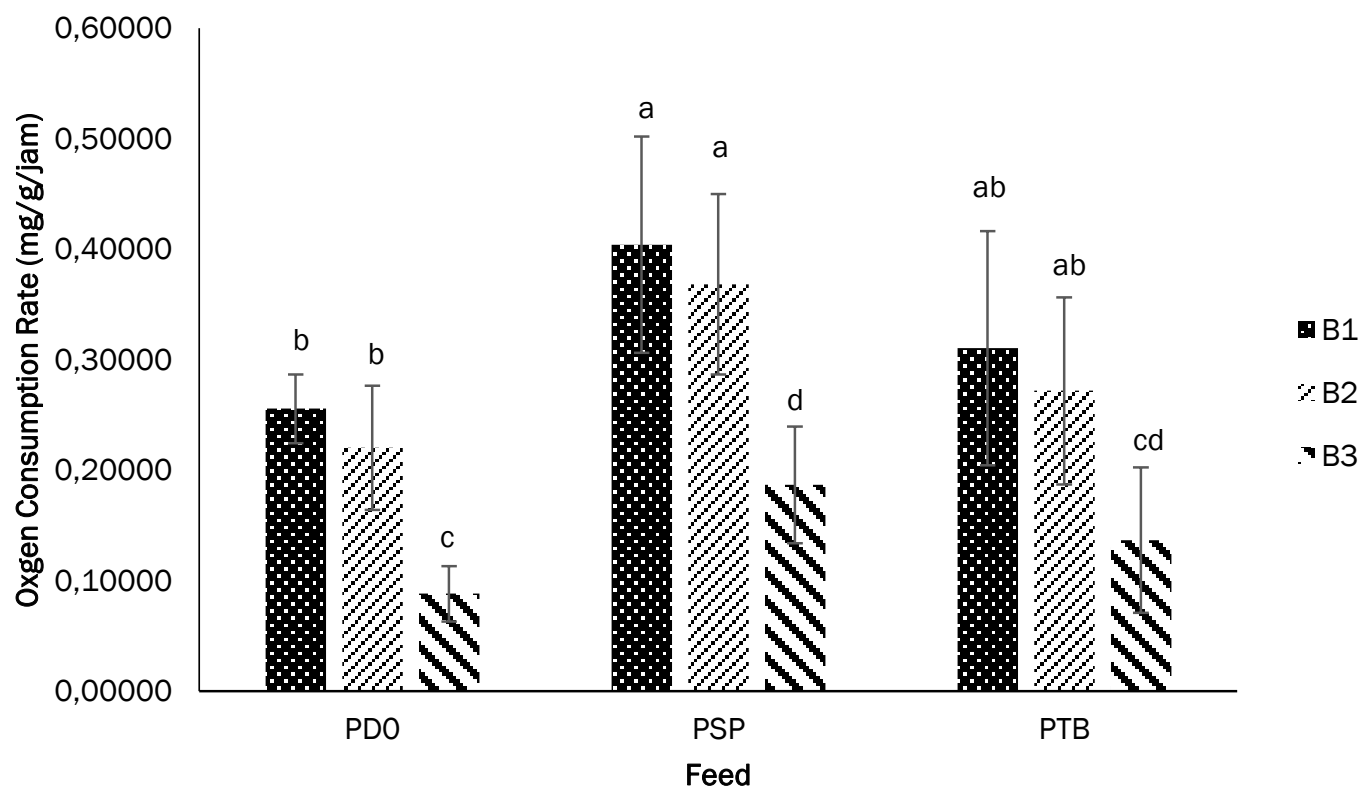

Figure 1. Oxygen consumption rate $( \pm S D)$ of Nereis $s p$. with various sizes that are maintained with different feeds. Different letters on the bar chart show significant differences between treatments $(P<0.05)$

from N. japonica calculated in weight loss units with weight gain, illustrating the universal principle that the metabolic rate per unit weight is often inversely related to body weight ( $\mathrm{Wu}$ and Sun, 2006). The same phenomenon is also shown in the experiment of Karyawati et al. (2004) on sea cucumbers with smaller body weight also showed a greater rate of oxygen consumption. According to Yuwono (2008), the rate of oxygen consumption is influenceds by several factors, including age, reproductive status, feed in the intestine, physiological stress, activity, season or ambient temperature, and body size.

\section{Conclusion}

The metabolic rate of worms Nereis $\mathrm{sp}$. influenced the type of feed and body size. The highest metabolic rate occurs in Nereis sp. with small body weight and which are feed Spirulina sp. (which has a high fiber content). Appropriate feed to support the growth of Nereis sp. is DO and tetra bits (low fiber feed).

\section{Acknowledgement}

This research was funded by DIPA BLU UNSOED. Special thanks to everyone that involved technically and non-technically, for the support and participation in this research.

\section{References}

American Public Health Association (APHA). 2005. Standard Methods for the Examination of Water and Waste Water $12^{\text {th }}$ ed. American Public Health Association Inc., New York.

Brougher, D.S., Douglass, L.W. \& Soares Jr, J.H. 2005. Comparative Oxygen Consumption and Metabolism of Striped Bass Morone saxatilis and its Hybrid M. chrysop $q \times$ M. saxatilis $\hat{\sigma}$. J. World Aquacul. Soc. 36(4): 521-529. doi: 10. 1111/j.1749-7345.2005.tb00400.x

Cook, J.T., McNiven, M.A. \& Sutterlin, A.M. 2000. Effect of Food Deprivation on Oxygen Consumption and Body Composition of GrowthEnhanced Transgenic Atlantic Salmon (Salmo salar). Aquaculture 188: 47-63. doi: 10.1016 /S0044-8486(00)00333-1

Darmadi, G., Suripto, \& Susanthi, K.I. 2003. Konsumsi Oksigen, Kadar $\mathrm{Hb}$ Darah, Dan Pertumbuhan Ikan Mas, Cyprinus carpio, Diberi Pakan Campuran Ampas Kelapa. J. Matematika dan Sains 8(2): 51-56.

Fidhiany, L. 1999. Pengaruh Umur dan Suhu Air pada Metabolisme Ikan Air Tawar Cichlasoma nigrofasciatum. J. Ilmu-ilmu Perairan dan Perikanan Indonesia, 1: 29-47. 
Karyawari, T, Hartati, R. \& Rudiana, E. 2004. Konsumsi Oksigen Teripang Hitam Konsumsi Oksigen Teripang Hitam (Holothuria atra) Pada Sistem Statis dan Sistem Dinamais. IImu Kelautan, 9(3): 169-173. doi: 10.14710/ik. ijms.9.3.169-173

Kristensen, E. 1984. Life Cycle, Growth and Production in Estuarine Populations of the Polychaetes Nereis virens and $N$. diversicolor. Holarct Ecol 7: 249-256. doi: 10.1111/j.160 0-0587.1984.tb01128.x

Liu, Y., Xian, W. \& Sun, S. 2009. Metabolism of polychaete Neanthes japonica Izuka: relations to temperature, salinity and body weight. Chinese J. Oceano. Limnol., 27(2): 356-364. doi: 10.1007/s00343-009-9130-2

Mustofa, A.G. 2012. Teknologi Pembesaran Cacing Nereis DendroNereis pinnaticirris (Grube 1984) [Disertasi]. Bogor: Departemen Budidaya Perairan, Fakultas Perikanan dan IImu Kelautan Institut Pertanian Bogor. 219 p.

Schmidt-Neilsen, K. 1990. Animal Physiology: Adaptation and Environment. $4^{\text {th }}$ Edition. Cambridge University Press, New York.

Sherwood, L., Klandorf, H. \& Yance, P.H., 2011. Animal Physiology From Genes to Organisms $2^{\text {rd }}$ Edition. Brooks/Cole, Cengage Learning, Belmont.

Wallace, R.A., Sanders, G.P. \& Ferl, R.J. 1991. Biology: The Science of Life, $3^{\text {rd }}$ Edition, Harper Collins Publishers Inc, New York. pp:669.

Wibowo, E.S., Palupi, E.S., Puspitasari, I.G.A.A.R., Atang \& Hana. 2018. Aspek Biologi dan Lingkungan Polychaeta Nereis sp. di Kawasan Pertambakan Desa Jeruklegi Kabupaten Cilacap: Potensinya Sebagai Pakan Alami Udang. Pancasakti Sci. Edu. J., 3(1): 18-24. doi: $10.24905 /$ psejv3i1.821
Wibowo, E.S., Palupi, E.S., Puspitasari, I.G.A.A.R., \& Atang, A. 2019. Sintasan dan pertumbuhan cacing Polychaeta Nereis sp. dari kawasan pertambakan Desa Jeruklegi Cilacap dengan salinitas media pemeliharaan dan jenis pakan berbeda. Depik 8(2): 67-75. doi: 10.13170/ depik.8.2.12155

Wibowo, E.S., Palupi, E.S., Puspitasari, I.G.A.A.R., \& Atang, A. 2019. Metabolism and Nutritional Content of Polychaeta Nereis sp. with Maintenance Salinity and Different Types of Feed. IImu Kelautan, 24(3):113-120. doi: 10.14710/ik.ijms.24.3. 105-112

Wu, B. \& Sun, S. 2006. Ammonia and urea excretion of the nemertean Procephalothrix simulus Iwata: effect of salinity, temperature, body weight and amputation. J. Exp. Mar. Biol. Ecol. 337: 13-18. doi: 10.1016/j.jembe.2006.05. 018

Yuwono, E. 2003. Studi Aspek Fisiologi untuk Aplikasi dalam Budidaya Cacing Lur (DendroNereis pinnaticirris.). Sains Akuatik 6(2): 66-74.

Yuwono, E. 2008. Fisiologi Hewan I. Fakultas Biologi. Universitas Jenderal Soedirman, Purwokerto.

Yuwono, E., Haryadi, B., Susilo, U., Siregar, A.S. \& Sugiharto. 2002. Fertilisasi Serta Pemeliharaan Larva dan Juvenil Sebagai Upaya Pengembangan Teknik Budidaya Cacing Lur. Biosfera, 9: 1-8.

Zimmermann, C. \& Kunzmann, A. 2001. Baseline Respiration and Spontaneous Activity of Sluggish Marine Tropical Fishes of the Family Scorpaenidae. Mar. Ecol. Prog. Ser. 219: 229239. doi: 10.3354/meps219229. 